\title{
実建物における室内化学物質モニタリングシステムの検証
}

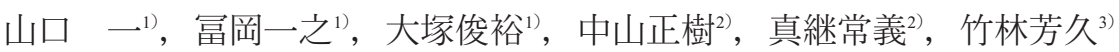

1)清水建設株式会社技術研究所 $=135-8530$ 東京都江東区越中島3-4-17

2)新コスモス電機株式会社＝532-0036 大阪府大阪市淀川区三津屋中2-5-4

${ }^{3)}$ 東北学院大学工学部 $=985-8537$ 宮城県多賀城市中央1-13-1

\section{Evaluation of indoor chemical substance monitoring system in office building}

\author{
Makoto YAMAGUCHI $^{1)}$, Kazuyuki TOMIOKA ${ }^{1)}$, Toshihiro OTSUKA ${ }^{1)}$, Masaki NAKAYAMA ${ }^{2)}$, \\ Tsuneyoshi MATSUGU ${ }^{2)}$ and Yoshihisa TAKEBAYASHI ${ }^{3)}$ \\ ') Shimizu Corp., 3-4-17, Etchujima, Koto-ku, Tokyo, 135-8530 \\ ${ }^{2)}$ New Cosmos Electric Co., Ltd., 2-5-4, Mitsuyanaka, Yodogawa-ku, Osaka, 532-0036 \\ ${ }^{3)}$ Tohoku Gakuin University, 1-13-1, Chuo, Tagajo, Miyagi, 985-8537

\section{要 旨} \\ ホルムアルデヒドやVOC等の室内化学物質によるシックハウス症候群や化学物質過敏症が問題となって \\ いる。さらに，最近では省エネルギー対策のため，室内 $\mathrm{CO}_{2}$ 濃度や在室人数によって外気導入量を制御する \\ 手法が注目されている。しかし，外気導入量の減少によって，室内化学物質が増加することを留意する場合 \\ は少ない。現在，これらの室内化学物質を測定するには，ガスクロマトグラフや高速液体クロマトグラフ等 \\ を用いる必要があり, 短時間で簡便に測定結果を得ることは出来ない。また，精度よく室内の化学物質濃度 \\ をモニタリングできるシステムも存在しない。我々は，これらの問題点を解消するために，半導体センサを \\ 用いた簡易のTVOC測定法を開発し，その成果を既報(-4) で発表してきた。本報では，2つの実建物に3種類の \\ 半導体センサを設置し, 各々のセンサの特性を評価し, 建物内の化学物質濃度のモニタリングに半導体セン \\ サが応用できることを確認し，今後の課題について報告する。
}

\begin{abstract}
Sick house syndrome and multiple chemical sensitivity syndrome caused by indoor chemical substances have become a problem. In addition, energy-saving measures to control the outside air intake rate according to indoor carbon dioxide concentration and the number of occupants have received attention in recent years. However, attention is rarely paid to the increase in indoor chemical concentration due to the decrease in the outside air intake rate. To measure the concentrations of indoor chemical substances, such as formaldehyde and volatile organic compounds (VOC), gas chromatography, high-performance liquid chromatography and other techniques need to be used and it is not easy to obtain measurements in a short time. Further, there are no systems capable of accurately monitoring the concentration of indoor chemical substances. To solve these problems, a simplified method of measuring the concentration of total volatile organic compounds (TVOC) using a semiconductor-based sensor was developed and the development results were presented in the previous report. This paper reports the evaluation results of the characteristics of three types of semiconductor-based sensors installed in two buildings, the results of confirmation that the semiconductor-based sensors could be used for monitoring the concentration of chemical substances in the buildings, and the subjects for future study.
\end{abstract}

Key words: 半導体センサ (Semiconductor-based sensor), 総揮発性有機化合物 (TVOC; Total volatile organic compounds)，室内空気質(Indoor air quality)，シックハウス症候 群 (Sick house syndrome)， ニオイセンサ(Odor sensor), 建物モニタリング (Building monitoring)

\section{1.はじめに}

室内のホルムアルデヒド $(\mathrm{HCHO})$ や揮発性有機化 合物(Volatile Organic Compounds; VOC ${ }^{\text {i⿱11) }}$ )による, シックハウス症候群や化学物質過敏症等が問題となっ

受付：2010年4月8日(Received：8 April 2010)

受理：2010年6月29日 (Accepted：29 June 2010)
ている ${ }^{5-8)}$ 。これらの問題を解決する場合，ホルムア ルデヒドやVOC等の測定やモニタリングを行うこ

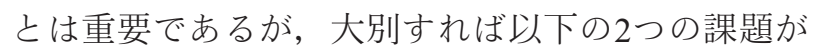
存在すると考えられる。

第1に，室内の化学物質は比較的低濃度であり， ガスクロマトグラフ $(\mathrm{GC})$, ガスクロマトグラフ質 
量分析装置 (GC/MS)及び高速液体クロマトグラフ （HPLC)等の精密法によって測定されてきた。これ らの方法は精度が高い反面, 専門知識や技術が必要 であり, 専用装置による繁雑な分析操作を必要とし た。そのため，測定結果を即座に得ること，多量の 測定を一度に処理すること, 連続して測定すること 等が困難であった。

第2に，建築基準法では，ホルムアルデヒド等の 室内化学物質対策のため, 住宅等では換気回数 0.5 回/h以上(外気導入量)の機械換気設備の設置を義務 付けている。また，オフィスビル等の建物(特定建 築物) の必要取入外気 $(\mathrm{OA})$ 導入量の設計は, 建築物 衛生法 (旧ビル管理法)や建築基準法に則り ${ }^{9,10)}$, 室 内 $\mathrm{CO}_{2}$ 濃度を $1,000 \mathrm{ppm}$ 以下に維持するため, 通常は 外気導入量を 25 から $30 \mathrm{~m}^{3} / \mathrm{h} ・ 人 に$ 設定される。しか し最近は, 省エネルギーの観点から, 室内に設置し た人感センサ, 画像解析, Radio Frequency Identification(RFID) タグあるいは無線端末等より在室人数 を推定したり， $\mathrm{CO}_{2}$ 濃度センサにより室内 $\mathrm{CO}_{2}$ 濃度 を直接にモニタリングし 注2 2 , 各部屋(各エリア)の冷 暖房や照明ばかりでなく外気導入量を制御する手法

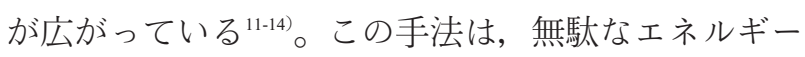
を節約し，たとえば照明で約 7\%，外気導入量の制 限で約 $13 \%$ の $\mathrm{CO}_{2}$ 排出量の削減を実現した例もあ る ${ }^{14)}$ 。この中で, 外気導入量の制御は, 上述したよ うに $\mathrm{CO}_{2}$ の主な発生源である居住者 (執務者)による室内 $\mathrm{CO}_{2}$ 濃度を基準 としており, 建材・備品・什器等か ら放散する種々の化学物質を考慮し ていない。したがって， $\mathrm{CO}_{2}$ 濃度の みを基準に外気導入量を制御すると， 室内の化学物質濃度の上昇を引き起 こす可能性がある。

我々は, これらの課題を解決する ため，VOCを簡便で迅速かつ多量 に測定・評価でき，さらに建物内の 化学物質濃度をモニタリングできる 手法を確立するため, 半導体センサ による総揮発性有機化合物 (Total VOC；TVOC）の簡易测定法を検討 してきた。既に, 半導体センサによ る化学物質発生源の検出法(原位置 測定), トルェン，キシレン，エチ ルベンゼン，スチレン(芳香族VOC)
の簡易測定装置及びセンサによるTVOC測定の特性 について報告した ${ }^{1-4)}$ 。本報では, 2件の実建物での 半導体センサによる室内化学物質のモニタリング結 果と半導体センサによる室内TVOC濃度モニタリン グの可能性について報告する。

\section{2. 実施方法}

\section{2- 1 実建物の概要}

試験対象の2件の建物について, その概観と概要 を写真1および表1に示す。建物 $\mathrm{A}$ は，平成15年11月 に竣工した地上 $6 \mathrm{~F}$, 延床面積が約 $9,600 \mathrm{~m}^{2}$ の事務所 ビルであり, 内装む通常の事務所仕様である。建物 $\mathrm{B}$ は平成18年7月に竣工した地上 $3 \mathrm{~F}$, 延床面積が約 $300 \mathrm{~m}^{2}$ で, 主用途は倉庫であるが, 種々な設備の性

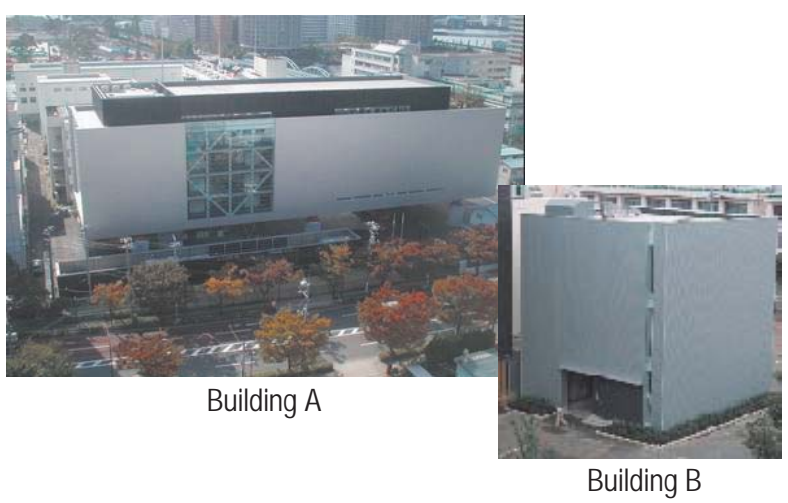

Photo 1 Appearance of the building

Table 1 Outline of the buildings

\begin{tabular}{|c|c|c|}
\hline Building & A & B \\
\hline Location & \multicolumn{2}{|c|}{ Etchujima 3-chome, Koto-ku, Tokyo } \\
\hline Major uses & Research laboratory (office) & Research laboratory (warehouse) \\
\hline Year of completion & Nov. 2003 & Jul. 2005 \\
\hline Number of stories & $6 \mathrm{~F}$ & $3 \mathrm{~F}$ \\
\hline Structure & S, partly RC & S \\
\hline Building area & $1,828 \mathrm{~m}^{2}$ & $136 \mathrm{~m}^{2}$ \\
\hline Total floor area & $9,634 m^{2}$ & $298.5 \mathrm{~m}^{2}$ \\
\hline Roof & $\begin{array}{l}\text { Deck plate for structural use, } \\
\text { thermal insulation, sheet- } \\
\text { applied membrane waterproofing }\end{array}$ & $\begin{array}{l}\text { Deck plate for structural use, } \\
\text { thermal insulation, asphalt } \\
\text { membrane waterproofing }\end{array}$ \\
\hline Exterior finishes & $\begin{array}{l}\text { Gasket curtain wall, Alstar steel } \\
\text { sheet }\end{array}$ & Galvalume steel sheet \\
\hline Interior finishes & $\begin{array}{l}\text { Floor: GRC free access floor } \\
\text { (partly ordinal free access floor) } \\
\text { Wall: steel wall, glass, partly } \\
\text { gypsum board (with EP finish) } \\
\text { Ceiling: flat deck, partly rock } \\
\text { wool acoustic board }\end{array}$ & $\begin{array}{l}(2 \mathrm{~F}) \\
\text { Floor: dustproof paint finish } \\
\text { Wall: PB } \\
\text { Ceiling: deck plate } \\
(3 \mathrm{~F}) \\
\text { Floor: P tile } \\
\text { Wall: painted calcium silicate board } \\
\text { Ceiling: calcium silicate board }\end{array}$ \\
\hline
\end{tabular}


能検証を行えるように， $2 \mathrm{~F}$ の一部に機械室を， $3 \mathrm{~F}$ に試験用の執務室を設置した。また，室内TVOC屯 種々の濃度に調整できるように, 試験の条件により 外気導入量を変化させた。

\section{2-2 半導体センサ}

本報で使用するセンサは, ニオイセンサ, 空気污 れセンサ, VOCセンサの3種類であり，金属酸化物 半導体表面でのガスの吸着と反応による電気伝導度 変化を, センサ両端の抵抗值変化として測定する半 導体センサである。半導体センサは高感度であるが, 特定のガスに対する選択性を持たすことが困難であ る。酸化物半導体材料の選択や触媒添加による表面 処理により，これらの欠点を改良した。

二オイセンサは，酸化スズ表面に塩基性酸化物を 添加し, 酸化スズが持つ固有の酸化活性の抑制を行 い, 水素や一酸化炭素等無臭の還元性ガスの感度を 抑制し，有臭ガスに高い選択性を持たせ，二オイに 対する高感度を実現させている ${ }^{15)}$ 。空気污れセンサ は，特定のガスに対する選択性を持たさず，水素及 び多種類の有機溶剤に対して高感度である。VOC センサは, 半導体材料に酸化インジウムを用い, ベー ス出力の湿度依存性を抑制している。さらに, 触媒 添加により半導体表面の活性制御を行い水素感度を 抑制させ，トルエン等のVOCに対する感度を向上 させている ${ }^{16)}$ 。

VOCのような還元性ガスによるセンサ電気抵抗 の变化は, その濃度と指数関数の関係を持ち, 一定 の濃度範囲において，次式で表すことが可能である。

$$
R=K C^{n}
$$

$R$ ：センサ抵抗值, $K, n$ : 定数, $C$ : ガス濃度 半導体式センサの反応性は(1)式のように, セン サ部の抵抗值で評価するが，センサ部をブリッジ回 路等の電気回路に組み込んで使用する場合, 抵抗值 変化を電気回路の偏差電位として取り出し, 電気的 出力 $(V)$ で評価する。ガス感度 $\Delta V$ は清浄空気中で の電気的出力を $V 0$, ガスがある時の出力值を $V t$ とすれば式(2)と定義される。

$\Delta V=V t-V 0$
$\Delta V$ とガス濃度 $C$ の関係式は, (1) 式と同様に次式 となる。

$$
\Delta V=K^{\prime} C^{n^{\prime}}
$$

$K^{\prime}, n^{\prime}$ : 定数

また, (3)式は, 半導体センサの值と化学物質濃 度の関係を表す次式に変換できる。

$$
S=A \times \log _{10} C+B
$$

$S$ : 半導体センサの值, $A, B$ : 定数

いま，室内の $\mathrm{n}$ 種類の化学物質濃度を $C 1, C 2 \cdots$, $C n$ とし, 各々の物質の単独の半導体センサ值を $S 1$, $S 2, \cdots, S n$ とする。各々の化学物質濃度(たとえ ば $\mathrm{Ci}$ )をトルエン換算した化学物質濃度 $($ Ctvoc) に 換算し, 室内での半導体センサ值 $($ Stvoc) とトルエ ン換算した全濃度には，(4)式から(5)式が成り立つ ことは既に報告している3)。

$$
\begin{aligned}
S_{\text {tvoc }} & =A_{t} \times \log _{10} C_{\text {tvoc }}+B_{t} \\
& =A_{t} \times \log _{10} \sum_{i=1}^{n} 10^{\left\{\left(A_{t} \times \log _{10} C_{i}+B_{i}-B_{i}\right) / A_{t}\right\}}+B_{t}
\end{aligned}
$$

$A_{t}, B_{t}$ : トルエンの定数

\section{2-3 センサモニタリングユニット}

上記の3種類のセンサを，専用ユニットに組込ん だ(写真2)。このユニットを建物 $\mathrm{A}$ は $3 \mathrm{~F}$ と $4 \mathrm{~F}$ 執務室, $4 \mathrm{~F}$ リフレシュコーナー及び $6 \mathrm{~F}$ 応接室に, 建物Bは $2 \mathrm{~F}$ と3Fに，各々1個ずつ設置した。図1に4F執務室で の2カ所のモニタリング位置(測定点)を示し, 写真3 に建物 $\mathrm{A} の$ 各所へ設置したセンサユニットを示す。

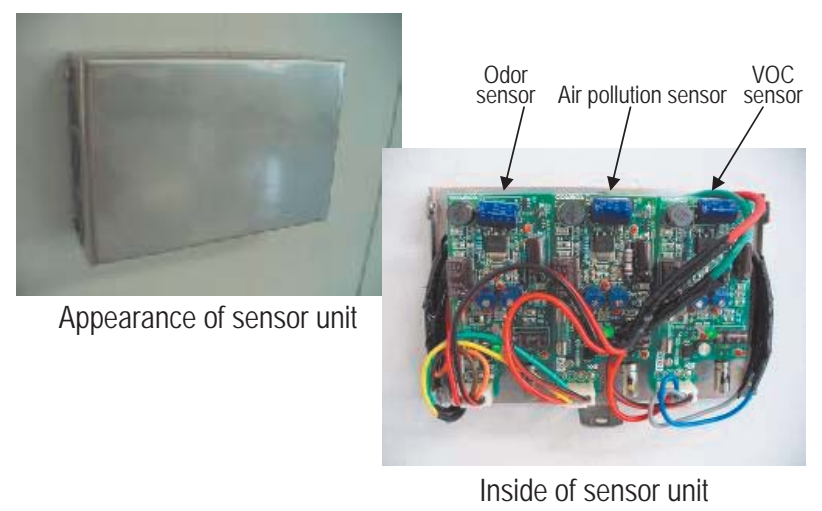

Photo 2 Sensor and sensor unit 


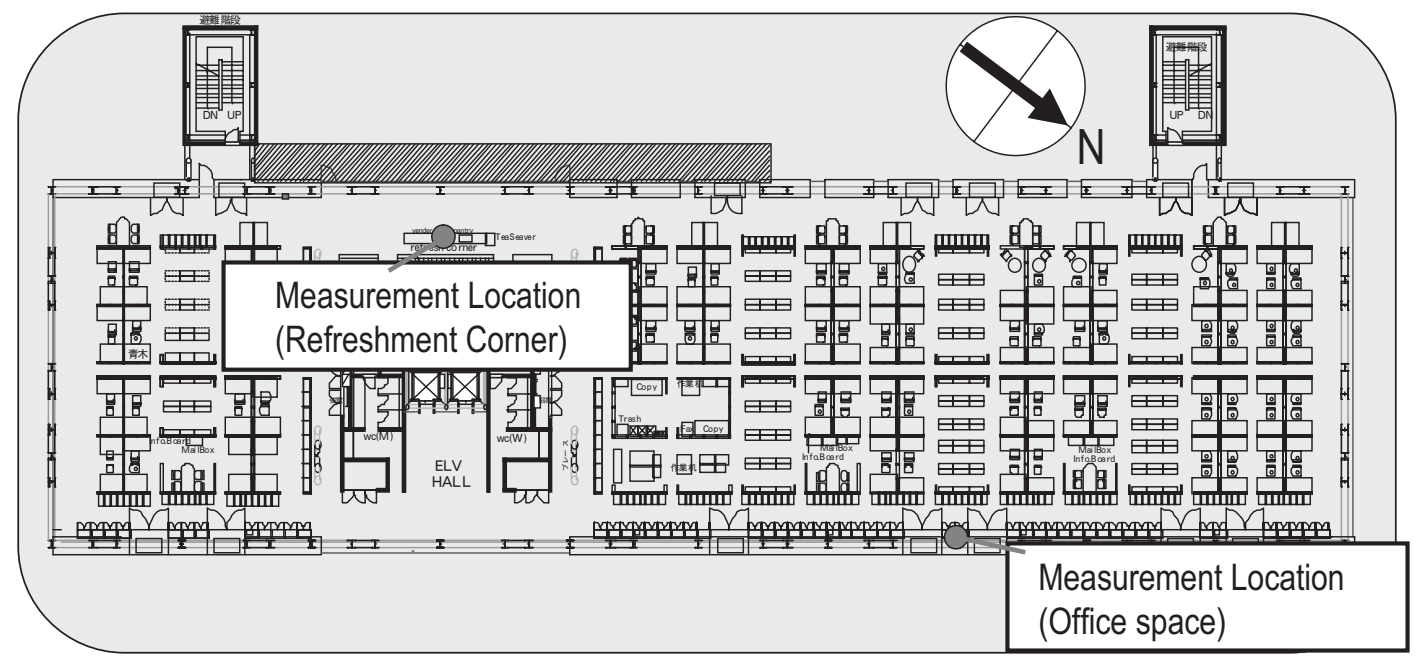

$3 \mathrm{~F}, 6 \mathrm{~F}$ also have sensors installed.

Fig.1 Ground plan in 4th FL of Building A
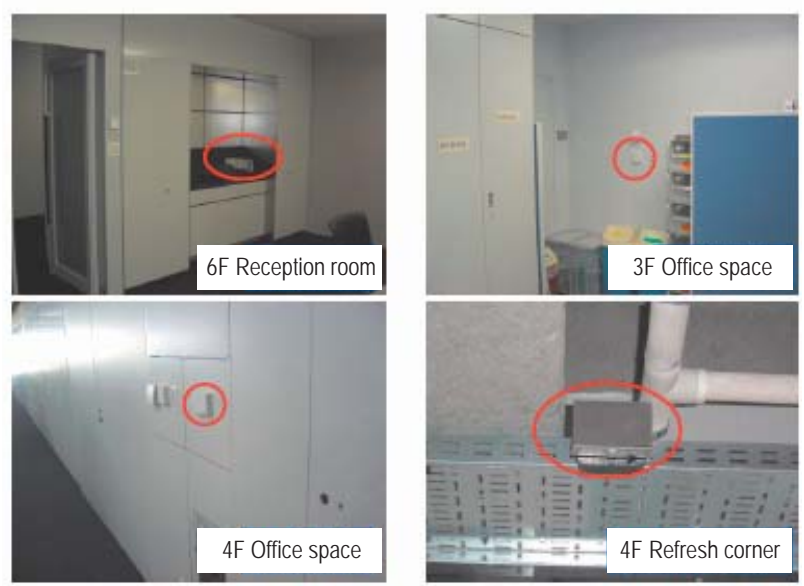

\section{2-4 室内化学物質濃度のモニタリング}

建物 $\mathrm{A}$ の室内の化学物質 (TVOC) 濃度に応じた各 センサの出力 (1-5V)を, WEB対応のSCADA(Supervisory Control and Data Acquisition)ソフトを採用し たビル管理システムを通じて, 中央管理室ばかりで なく, 社内ネットワーク上のどのパーソナルコンピュー 夕 $(\mathrm{PC})$ でも, WEBブラウザより本管理システムに アクセスでき, 室内の状況がモニタリングできるよ うにした(図2)。建物Bも同様に社内ネットワーク からモニタリングデータを収集した。

Photo 3 Setting situation of the sensor unit in Building $A$

\section{$6 \mathrm{~F}$ server room route}

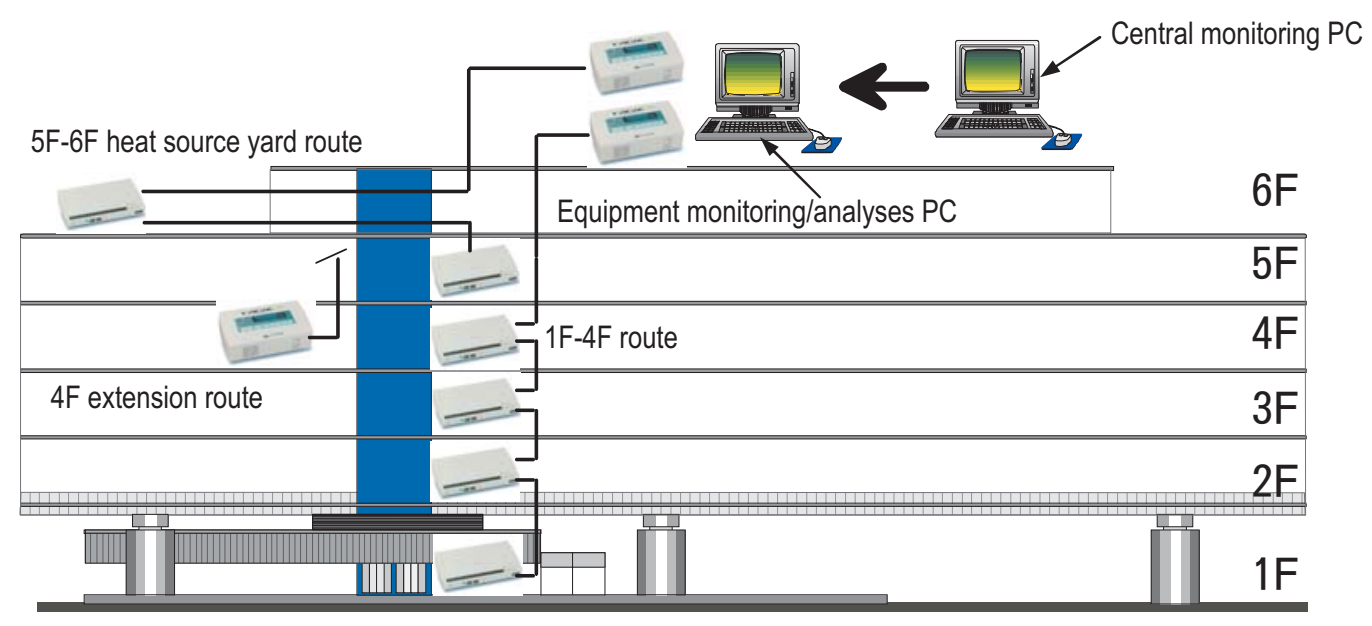

1F heat source yard route

Fig.2 Equipment monitoring system route diagram 


\section{2-5 室内化学物質濃度の測定}

VOCの測定は, Tenax GRに試料空気を通常 $10 \mathrm{~L}$ 捕集し, 加熱脱着後, $\mathrm{GC}$ (FID〔水素炎イオン化検出 器了, 島津製作所 $\mathrm{GC}-17 \mathrm{~A}$; キャピラリーカラム : J \&W社製ワイドボアカラム125-1035)にて分析・定 量した。TVOC濃度は, このGCを使用し, 概放n一へ キサンからn-ヘキサデカンまでの範囲で検出された VOCの総量をJIS A19017) に準拠しトルェン換算し た。また，VOC成分の同定は，VOC濃度測定と同 様に試料空気を捕集したTenax GRを, GC/MS(島津 製作所QP-5000；キャピラリーカラム)にて分析・ 同定した。

ホルムアルデヒド及びその他カルボニル濃度の測 定には, $\operatorname{DNPH}(2,4-$ ジニトロフェニルヒドラジン $)$ サンプラ(Waters製)を用いて，22.5 Lの試料空気を 捕集し, アセトニトリルで溶媒抽出後, 高速液体ク ロマトグラフ（Hewlett Packard；HP1100)にて分析・ 定量した。温湿度の測定には, 温湿度センサ（おん どとり，TR-72S，ティアンドディ)を用い，連続的 にデータを収集した。

\section{2-6 室内化学物質の捕集条件}

建物Aでは, 機械換気運転前 (午前7:00 8:00) に, 比較的高濃度の化学物質の空気試料を捕集した。建 物Bでは午後13:00〜14:00の時間帯で, 竣工年の平 成18年では機械換気量を調節して種々の化学物質濃 度の空気試料を捕集し, 平成19年以降は室内化学物 質濃度が自然減衰するため機械換気を停止した条件
で捕集した。また，試料空気の捕集位置は床から $1.2 \mathrm{~m}$ で, 厚生労働省の方法 ${ }^{18}$ に準じたが, 対象建物 では捕集前の空開け換気を実施せず, 通常の建物使 用条件下での室内空気の捕集とした。

\section{3. 結果}

\section{3-1 対象建物の化学物質濃度}

建物 $\mathrm{A}$ 之建物 $\mathrm{B}$ は竣工時加ら年に6回以上，定期的 に建物内の室内化学物質濃度を測定してきた。3種 類のセンサを設置した建物 $\mathrm{A} の 3 \mathrm{~F}, 4 \mathrm{~F}$ と $6 \mathrm{~F}$ の測定結 果を図3に，建物 $\mathrm{B}$ の $2 \mathrm{~F}$ と $3 \mathrm{~F}$ の測定結果を図4に示す。 建物A $\mathrm{A}$, 竣工後直ぐに内装の改修等を行ったため, $3 \mathrm{~F}$ 執務室は平成16年1月から，6F応接室は平成16年 3月からのデー夕を記載した。竣工時点で, 全ての 測定箇所のホルムアルデヒド，アセトアルデヒド， 及びVOCの濃度は厚生労働省の指針值 ${ }^{18}$ 未満であっ たが(表2), 夏季には，化学物質濃度が上昇するこ とを確認した。これは, 測定が空調稼動前であり, 外気(以下OA)の導入がなく室内温度も高いこと, 建材ばかりでなく什器・備品からの化学物質の放散 が主要な原因と考えられる ${ }^{19)}$ 。空調(機械換気) 稼動 時には, 常に室内TVOC濃度は暫定目標值の $400 \mu \mathrm{g} /$ $\mathrm{m}^{3}$ 以下であることを確認している。

建物Bの主用途は倉庫であり, $3 \mathrm{~F} に は$ は試験用の執 務室はあるが，通常は執務者はいない。また，室内 TVOCも種々の濃度に調整できるように, 内装材・ 下地材は通常の製品で施工し, 竣工時の平成18年は 外気導入量を 0 回 $/ \mathrm{h}, 2.6$ 回 $/ \mathrm{h}, 5.3$ 回 $/ \mathrm{h}$ 之変化させ,

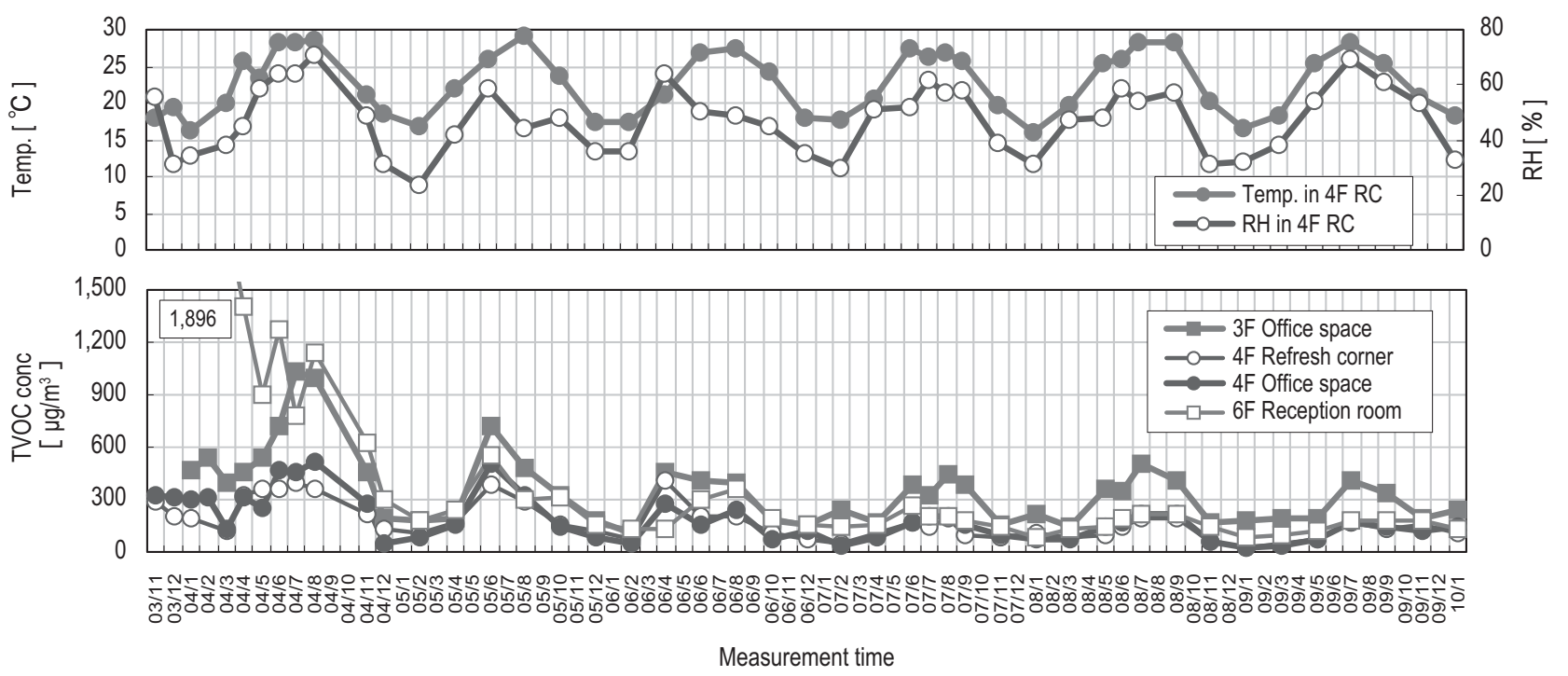

Fig.3 TVOC concentration, temperature and relative humidity in Building A (before running air conditioning) Numerical values in boxes in the drawings are TVOC concentrations of reception room (March 2004). 


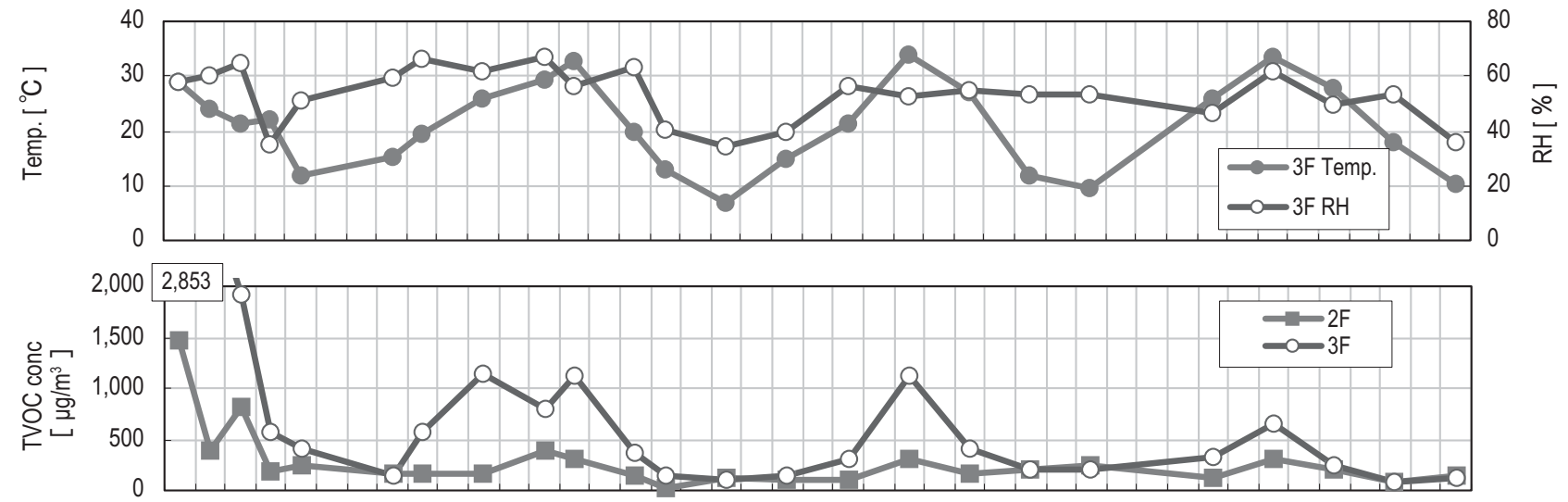

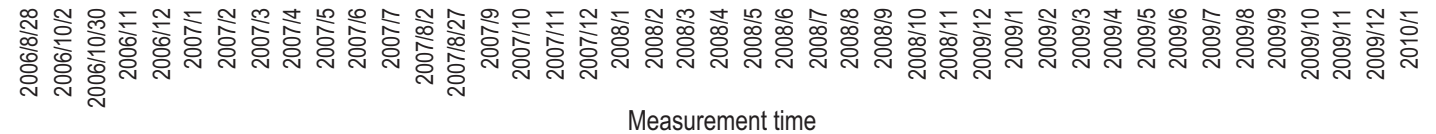

Fig.4 TVOC concentration, temperature and relative humidity in Building B (before running air conditioning) Numerical values in boxes in the drawings are TVOC concentrations of 3F (October 2006).

Table 2 Indoor chemical substance concetration in 4th floor of Building A

\begin{tabular}{|c|c|c|c|c|c|c|c|c|}
\hline $\begin{array}{l}\text { Measurment } \\
\text { Time } \\
\text { substance }\end{array}$ & 2003/11 & $2004 / 1$ & $2004 / 8$ & $2005 / 2$ & $2005 / 6$ & $2006 / 4$ & $2006 / 8$ & $2007 / 4$ \\
\hline TVOC & 322 & 300 & 516 & 79 & 499 & 273 & 238 & 84 \\
\hline Toluene & 27 & 79 & 22 & 16 & 54 & 54 & 11 & 14 \\
\hline Ethyl benzene & 8 & 6 & 12 & 3 & 8 & 8 & 7 & 3 \\
\hline Xylene & 11 & 12 & 38 & 6 & 20 & 17 & 16 & 4 \\
\hline p-Dichlorobenzene & 22 & 9 & - & 13 & 83 & 36 & 62 & 25 \\
\hline Styrene & 2 & 1 & 6 & - & 3 & 2 & 4 & - \\
\hline Tetradecane & 3 & 2 & 8 & - & 2 & - & 2 & - \\
\hline Formaldehyde & 12 & 8 & 35 & 4 & 26 & 14 & 26 & 14 \\
\hline Acetaldehyde & 10 & 9 & 1 & 5 & 18 & 2 & 12 & 8 \\
\hline
\end{tabular}

Table 3 Indoor chemical substance concetration in 3rd floor of Building B

\begin{tabular}{|c|c|c|c|c|c|c|c|}
\hline Measurment $\begin{array}{r}\text { Measurment } \\
\text { Time } \\
\text { Material }\end{array}$ & $2006 / 8$ & $2007 / 3$ & $2007 / 8$ & $2008 / 1$ & $2008 / 7$ & $2009 / 1$ & $2009 / 7$ \\
\hline TVOC & 9,979 & 137 & 1,119 & 92 & 1,132 & 205 & 661 \\
\hline Toluene & 386 & 19 & 140 & 12 & 154 & 29 & 136 \\
\hline Ethyl benzene & 99 & 5 & 12 & 2 & 10 & 4 & 7 \\
\hline Xylene & 366 & 8 & 32 & 3 & 28 & 13 & 20 \\
\hline p-Dichlorobenzene & 381 & 4 & 75 & - & 73 & - & 53 \\
\hline Styrene & - & - & - & - & - & - & - \\
\hline Tetradecane & - & - & - & - & - & - & - \\
\hline Formaldehyde & 58 & 13 & 145 & 8 & 121 & 5 & 132 \\
\hline Acetaldehyde & 65 & 8 & 38 & 6 & 45 & 9 & 35 \\
\hline
\end{tabular}

TVOC濃度を最高 $9,979 \mu \mathrm{g} / \mathrm{m}^{3}$ から最低 $53 \mu \mathrm{g} / \mathrm{m}^{3}$ までの 濃度範囲に設定した。室内化学物質濃度は年々低減 し，平成19年以降は全ての測定箇所のホルムアルデ
ヒド，アセトアルデヒド，及びVOCの濃度は厚生 労働省の指針值未満であった(表3)。しかし，夏季 にはTVOC濃度は暫定目標值以上となっていたが, 
平成19年以降の測定は換気なしの条件であり，建物 Bは通常は使用しておらず，換気による低減効果が なかったためと推察できる。

\section{3-2 半導体センサによる室内TVOC濃度の モニタリング}

図5に，建物 $\mathrm{A}$ 内に設置した 3 種類のセンサ值の平 成19年4月8日から15日までの変化を示す。通常，平 日の8:00から18:00までは就業時間であり，事業用 PHS (Personal handyphone system) を用い在館人数 の制御を行い，1人当たり $25 \mathrm{~m}^{3} / \mathrm{h}$ の外気導入を実施 し，室内 $\mathrm{CO}_{2}$ 濃度を700ppm以下に維持した。外気が 導入されTVOC濃度が低下する間は, 各センサ值が 低下し，空調停止後に上昇することが確認できた。 特に $4 \mathrm{~F}$ と $5 \mathrm{~F}$ の執務室は，4月10日，12日及び13日の 10:00から 18:00は外気冷房(1フロア約 $70 \mathrm{~m}^{3} /$ 分)を実 施したためセンサ值は急激に低下したが，6Fの応 接室は外気冷房を実施しなかったのでセンサ值の急 激な低下はなかった。また，4月8日に一過性のセン サのピークが確認できるが，このピークは当日の内

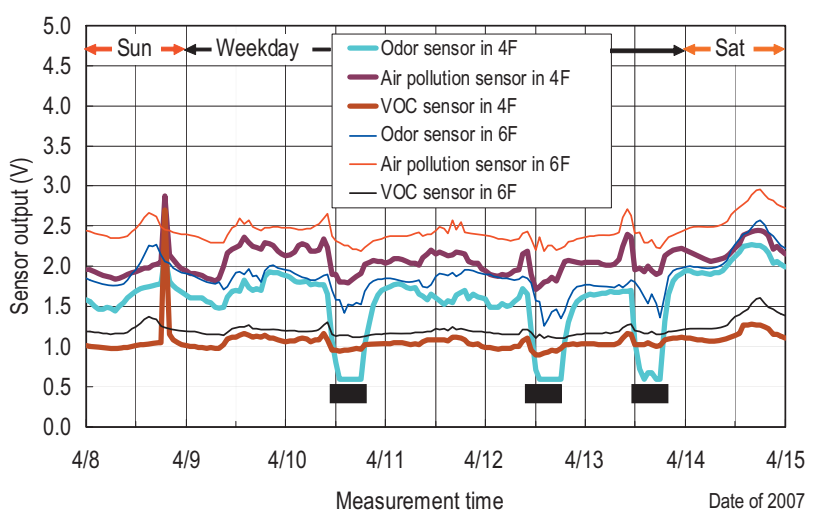

Fig.5 Monitoring of the sensor in Building A Fresh air cooling applied areas are shown as bars ( $\square$ ).

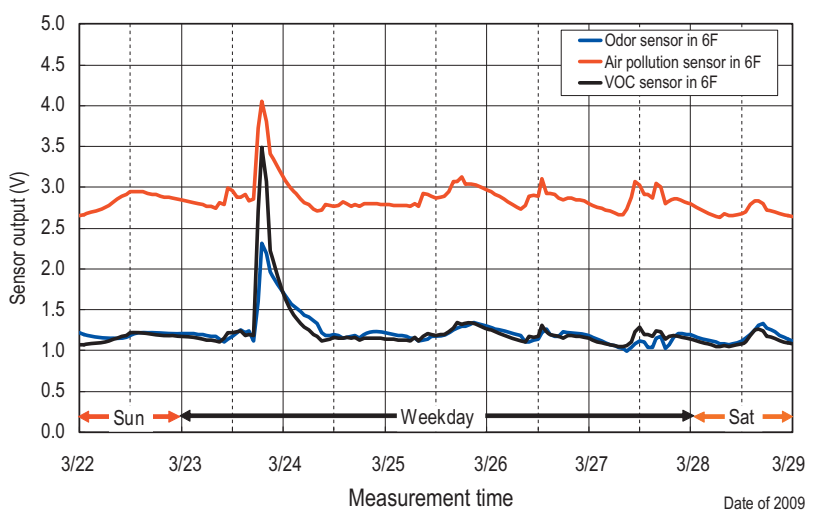

Fig.6 Monitoring of the sensor in Building A
装の補修工事が原因と考えられる。6Fの応接室で は使用時間帯でのみで空調が稼動し, 図6でも平成 21年3月23日に1度のピークの上昇が確認できた。こ れは，6Fの応接室で午後に飲食した場合の臭気等 をセンサが感知したと考えられる。

このように，今回設置した3種類の半導体センサ は，室内の化学物質濃度，換気 ( $\mathrm{OA}$ 導入)やオフィ ス内のイベント等で, 各々のセンサの反応性は異な るがよく感知し, 室内の化学物質濃度をモニタリン グするッールとして応用できることが確認できた。

\section{3-3 外気導入時における半導体センサ值と 室内TVOC濃度}

年間を通じて，外気導入時における半導体センサ 值と室内TVOC濃度を検討した。図7に，建物Aにお ける夏季の二オイセンサ值と外気導入量の関係の一 例を示す。前述したように, 通常は建物 $\mathrm{A}$ の執務室 では平日は8:00から18:00まで空調が稼動し, 外気 が導入されTVOC濃度が低下する間は二オイセンサ 值は低下し，空調停止後に上昇することが確認でき た。図8に，冬季に㧫結果を示す。冬季では， 空調稼動前ではTVOC濃度は $54 \mu \mathrm{g} / \mathrm{m}^{3}$ 以下であり,

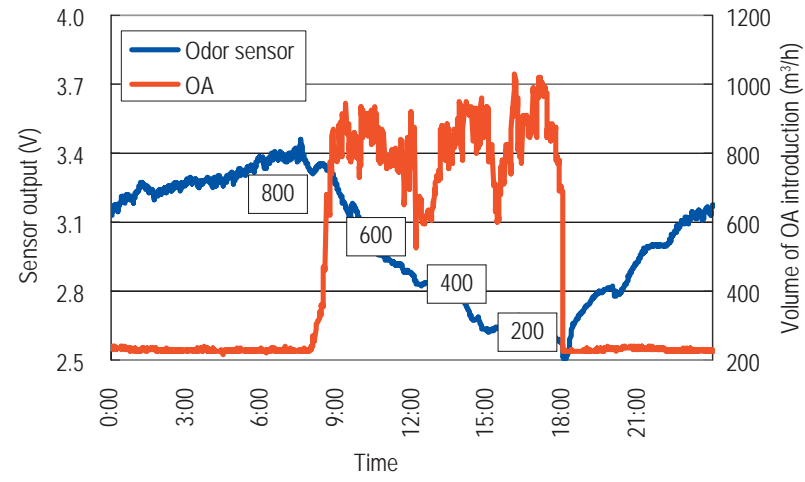

Fig.7 Relationship of the odor sensor output and ventilation open air volume in Building A (summer time)

The air conditioning operated from 8:30 to $18: 00$.

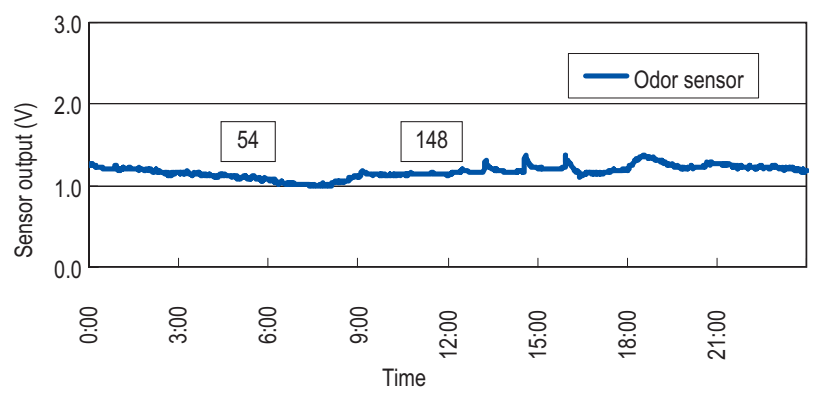

Fig.8 Relationship of the odor sensor output and ventilation open air volume in Building $A$ (winter time)

The air conditioning operated from 8:30 to $18: 00$. 
空調稼動後に若干濃度が上昇していた。この現象は, 建物 $\mathrm{A}$ が幹線道路の近傍に位置しており外気の TVOC濃度が室内より高濃度であること，あるいは 本建物が研究所の事務棟で通常より多くのオフィス 機器があり，執務時のこれら機器の稼動が主因であ ると考えられた。センサ值の変化が殆よ゙ないのは， TVOCの低濃度域の变化のためと推論できる。図9 に，中間期の結果を示す。空調稼動前ではTVOC濃 度は $273 \mu \mathrm{g} / \mathrm{m}^{3}$ であり, 空調稼動後に $119 \mu \mathrm{g} / \mathrm{m}^{3}$ に低下 していた。センサ值は，空調稼動時に若干低下して いることが確認できた。

図10に，建物Bの計測例として室内TVOC濃度が 高い夏季(平成18年8月29日)のニオイセンサの結果 を示す。午前 10 時から午後7時30分まで空調を稼動 した。外気導入の有無によってセンサ值は変動して いる。空調制御のため室内相対湿度はハンチングし, この湿度変化にセンサが応答しているが，モニタリ ングに支障はないと判断できる。また，他の2種類 のセンサも二オイセンサと同様な反応を示した。

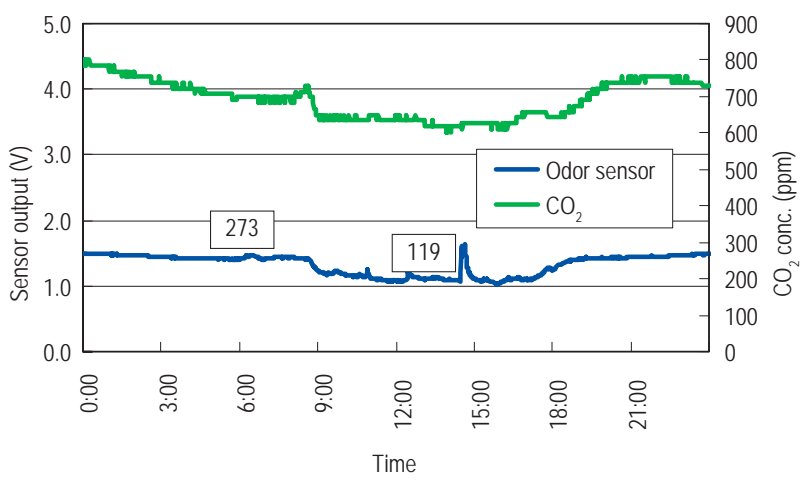

Fig.9 Relationship of the odor sensor output and ventilation open air volume in Building $\mathrm{A}$ (spring time) The air conditioning operated from 8:30 to $18: 00$.

\section{3-4＼cjkstart室内化学物質濃度とセンサ値との関係}

室内の化学物質 (TVOC)のモニタリングセンサと して可能性のある半導体センサについて，実際の室 内TVOC濃度と 3 種類のセンサ值の関係を求めた。 建物Bにおける竣工時から平成 19 年 5 月までの関係 を図11から図13に示す。センサの決定係数 $\left(R^{2}\right)$ は, ニオイセンサで約 0.83 ，空気污れセンサで約 0.80 , VOCセンサで約 0.83 となり，室内TVOC濃度のモニ

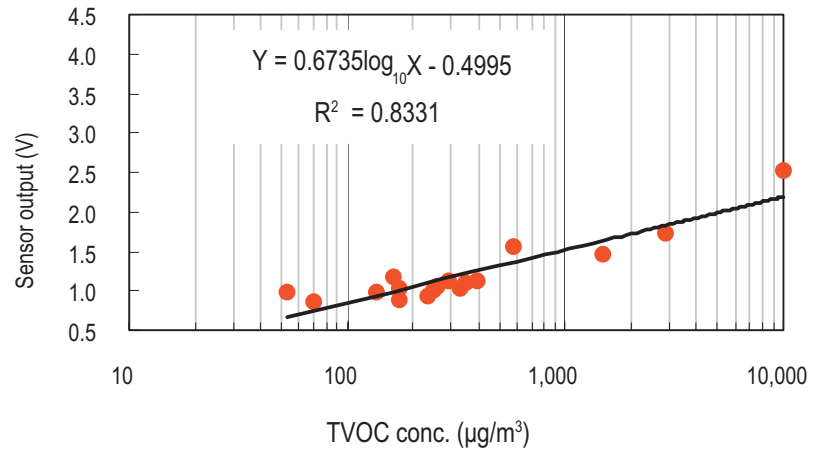

Fig.11 Relationship of the odor sensor output and TVOC concentration in 2nd and 3rd FL of Building B

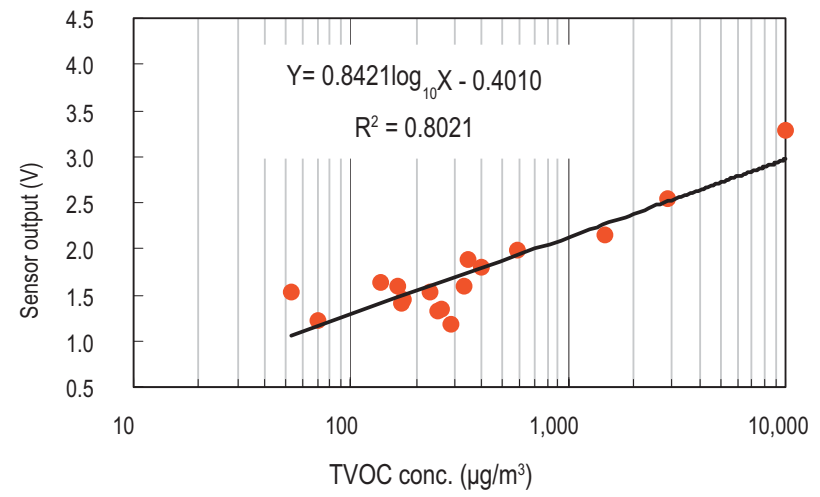

Fig.12 Relationship of the air pollution sensor output and TVOC concentration in 2nd and 3rd FL of Building $B$

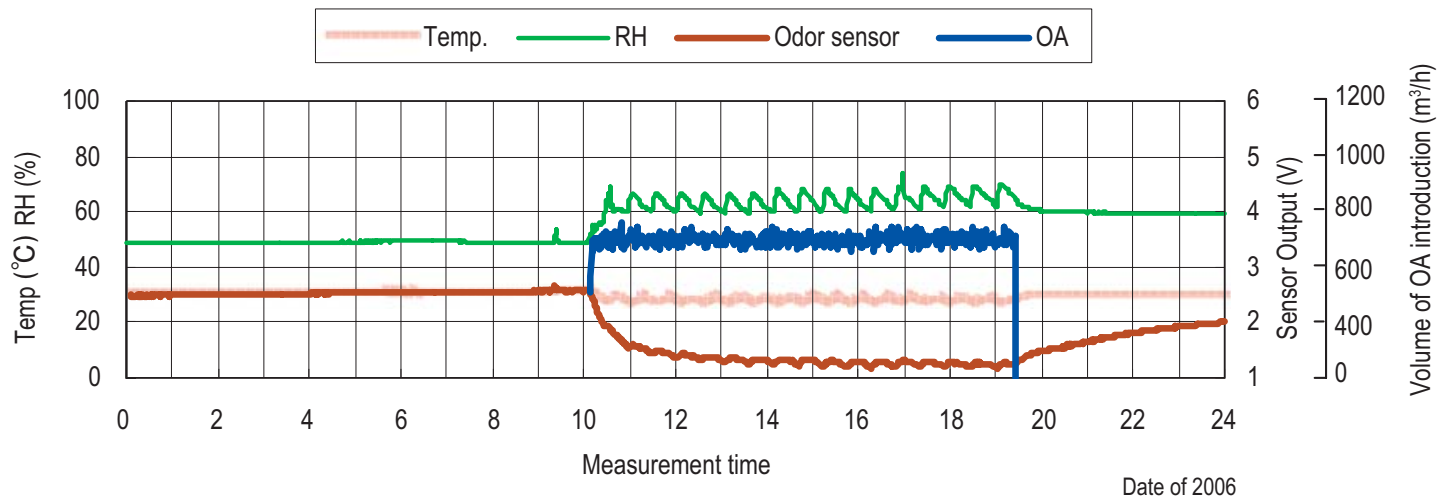

Fig.10 Monitoring of the odor sensor in Building B 


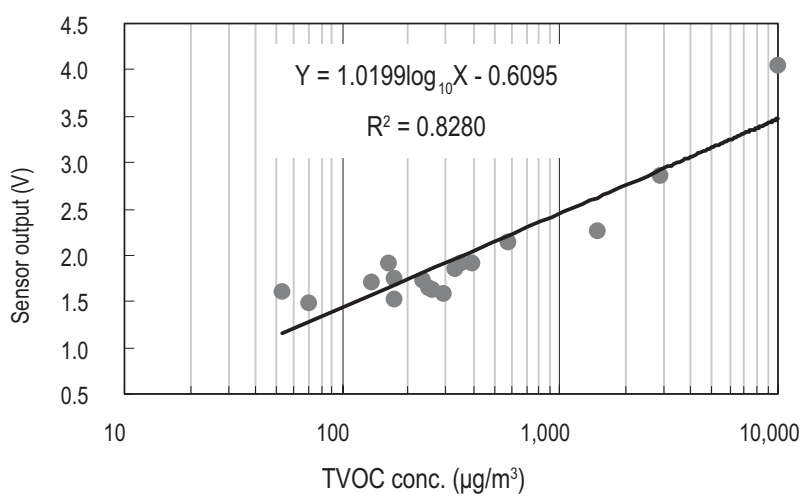

Fig.13 Relationship of the VOC sensor output and TVOC concentration in 2nd and 3rd FL of Building $B$

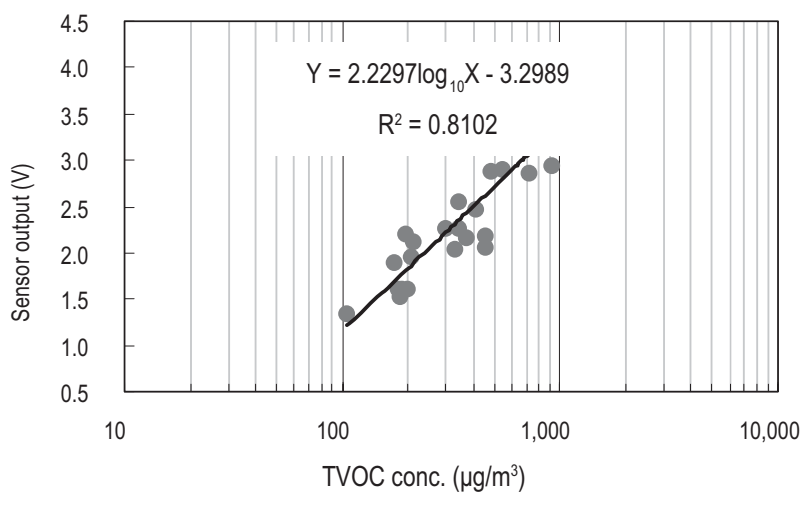

Fig.14 Relationship of the odor sensor output and TVOC concentration in 3rd FL of Building A

タリングとして使用できることが確認できた。今回, センサ值は安定しており経年変化は確認できなかっ た。但し， 3 種類のセンサの常用対数の相関式の各 定数は異なっており, 各センサの感度が異なること を示している。建物Aの竣工時から平成19年までの ニオイセンサ值と室内TVOC濃度の関係を図14に示 す。決定係数は約 0.81 であり, 建物B 之同様な常用 対数の相関式となったが, 定数が異なっていた。ま た, 建物Aでもセンサ值は安定しており, 経年変化 は確認できなかった。

\section{4. 考察}

我々は既報において1種類の半導体センサに関し, トルエンや䣷酸エチル等の単一の化学物質に対し上 述の常用対数の相関式(4)が成立するが, 単一の物 質毎に(4)式の定数 $A, B$ が異なること, すなわち感 度が異なることを示した。このような物質毎に感度 が異なる特性は, 半導体センサだけでなく, GC, GC/MSやHPLC等全ての測定装置も同じであり, 標
準物質によって検量線を作成し定量する必要がある。 さらに, チャンバー試験や新築建物内の複合の化学 物質 (TVOC) 濃度とも (5) 式が成り立つことを確認 し, 各ケースで化学物質 (TVOC)の各物質の組成・ 濃度が異なるので，(5)式の定数At とを示しだ3)。

本報では, 使用する半導体センサを3種類に増や し， 2 件の建物で竣工時から長期間のセンサのモ二 タリング試験を行った。今回の試験でも3 種類のセ ンサは, 各々に(5)式が成り立っていたが定数が異 なり，さらに同じセンサであってもモニタリングす る建物によって定数が異なることを示した。このよ うに同じセンサ值であっても，モニタリング対象が 異なれば室内TVOC濃度は異なる可能性があり，よ り正確な測定值を得るためには, 必要時に室内化学 物質濃度を精密法で測定し，この測定值と使用する センサ值での相関を取る必要がある。

また，本論文では，センサを設置後毎年6回以上， 定期的に室内TVOC濃度 (各VOC濃度) 精密法で測 定し，各センサ值の経年变化を確認した(図3，4)。 今回の測定条件では, センサ值は安定しており経年 変化は確認できなかった(図11，12，13，14)。実用 化に向けては，センサの劣化を留意する必要がある。 本論文で実施したように定期的に室内の化学物質濃 度を測定するか, 一定濃度の標準ガスを用いてセン サ值を確認し, センサの経年変化が認められた場合 は, センサの交換や校正が必要となる。但し, 今回 の測定結果から, 通常のオフィスビルでは5 年以上 安定して測定可能であると考えられる。

センサに電流が流れると, 検知素子である金属酸 化物の半導体が高温となり, 空気中の酸素分子がこ の部分に吸着し抵抗が上昇する。この半導体に, 空 気中のVOCばかりでなく臭気物質等の還元物質が 接触すると, 半導体上の酸素を奪い抵抗值が減少す るので, 還元物質濃度を測定することができる ${ }^{20)}$ 補修工事でのVOCや飲食等の臭気の発生は短時間 であり, センサ出力值のピークは一過性(図5，6）

である。しかし, 建材等からのVOCは長期間発生 し, センサの出力值は一過性でなく建物の換気条件 にも影響された独特のピークパターンを示す(図5)。 したがって, 両者は容易に区別でき, センサ特性や 反応 (ピーク)パターンを充分に理解すれば, 建物内 のVOC対策ばかりでなく, 臭気対策等にも活用が 可能である。 
オフィスビル等の建物における室内の化学物質濃 度の増加は, 竣工時に押ける内装材や什器・備品加 らの発生ばかりでなく, 執務者が持ち込んだ日用品 やオフィス機器, 省エネによる外気導入量の制御や, 休日や夜間の執務時間以外での空調停止等が原因で ある。今回は, 建物内でのTVOC濃度のモニタリン グ結果のみを示しが，室内モニタリングを応用し， 室内TVOC濃度が高い場合は, 外気導入量を増やし たり，空調稼動開始時間を早めたり稼働時間を延ば す等の制御によって, 室内TVOC濃度の低下が可能 となろう。

実際の建物で長期間使用する場合は, 半導体セン サの特性を充分に把握する必要がある。高湿時の補 正, ブランク值上昇への対応, 低濃度時のセンサの 反応性の確認(標準物質での校正，センサ取換等)や 対象によってセンサの感度が異なる等の半導体セン サの欠点 15,16 を解消する必要がある。センサによる 測定が安定して継続できれば, 本報で使用したセン サの信頼性はより高くなり, 室内化学物質モニタリ ングッールばかりでなく, 室内空気質を良好に維持 するための制御系への展開活用も期待できる。

\section{5. まとめ}

- 室内の比較的低濃度の化学物質 (TVOC) 濃度をモ ニタリングできる半導体センサの特性を, 3 種類の センサを用い2 件の建物で, 竣工時から長期間試験 した。今回の測定条件では, 3種類のセンサ值は安 定しており, 経年変化は確認できなかった。

・センサ別, 建物別に感度は異なるが, センサ值と 室内TVOC濃度はよい相関を示すことを確認でき, 半導体センサによるモニタリングの有用性を示した。 ・但し, 同じセンサにおいてセンサ值が同じでも, 対象の物質組成や比率が異なれば, 室内TVOC濃度 は同一ではない可能性は高い。

・この点を解消するためには, 未知の対象物を半導 体センサでモニタリングする場合は, GC, GC/MS, HPLC等の精密法での測定值によってセンサ值を補 正する必要がある。

・更に半導体センサにより，VOCばかりでなく臭 気等の還元ガスもモニタリングでき, オフィスビル 等の建物の外気導入量や導入時間を効率よく制御す ることで, 室内TVOC濃度を適正に維持できる可能 性を示した。

\section{引用文献}

1）山口 一, 冨岡一之: 室内空気質の簡易測定法 の開発(第5 報), 二オイセンサによる化学物質 放散部位の特定法の評価, 空気調和衛生工学会 学術講演会論文集, 1387-1390(2004).

2）久世 恭, 山口 一: ポータブル型VOC分析 計を用いた新たな測定法, 日本建築学会学術講 演梗概集，905-906(2004).

3）山口一, 冨岡一之：半導体センサによる TVOCの簡易測定法の開発, 日本建築学会環境 系論文集，599，79-87(2006)。

4）山口一, 冨岡一之, 大塚俊裕, 栗原隆, 中山 正樹, 真継常義 : 室内空気質の簡易測定法の開 発(第11報), 実建物に打ける室内化学物質モ二 タリングシステム結果の比較, 空気調和衛生工 学会学術講演会論文集, 469-472(2007).

5) 日本建築学会: 特集健康建築, 化学物質室内空 気污染, 建築雑誌, 113(1421)(1998).

6）日本建築学会：特集健康建築，その2高気密 • 高断熱, 建築雑誌, 114(1438)(1999).

7) 日本建築学会 : 特集, シックハウスから健康住 宅へ, 建築雑誌, 117(1491)(2002).

8) 日本建築学会 : 特集, シックハウス問題は解決 したか, 建築雑誌, 119(1521)(2004).

9）国土交通省住宅局編集：改正建築基準法に関す る講習会テキスト「改正建築基準法に対応した 建築物のシックハウス対策マニュアル」, 工学 図書株式会社(2003).

10）ビル管理法令研究会：建築物衛生法, ぎょうせ い(2003).

11) Cristian Floerkemeier, Roland Schneider, Marc Langheinrich, Scanning with a Purpose - Supporting the Fair Information Principles in RFID Protocols. Ubiquitous Computing System 2004 (UCS2004), ISSN:0302-9743， 3598, 214-231 (2004).

12）藤森敬悟, 藤野友也, 川端理華, 石井 篤: 人 感センサデー夕による動線の推定, Data Engineering Workshop 2008(DEWS2008), D10-3(200 8).

13）帷子京市郎, 中村克行, 超卉莘, 柴崎克介：レー ザセンサを用いた歩行者通過人数数の自動計測 手法, Forum on Information Technology 2005(FIT2005), 145-148(2005). 
14）川島 実, 郷 正明, 小林勝広, 中村卓司: 次 世代技術を盛り込んだ環境配慮型建築 (第10報) 2004年度の運用実績, 空気調和衛生工学会学術 講演会論文集，1785-1788(2005).

15）福井 清：酸化錫半導体ガスセンサを用いた二 オイの計量, 臭気の研究, 20(4), 1-7(1989).

16）福井 清, 石川 博: 室内環境モニタリグ用セ ンサ, Electrochemistry, 4, 280-284(2001).

17）村上周三監修：シックハウス対策に役立つ小形 チャンバー法(JIS A1901), 日本規格協会(2003).

18）厚生労働省ホームページ：http://www.mhlw.go.jp/

19）朱清宇, 加藤信介, 安宅勇二, 徐長厚 : 家具な ごからの揮発性有機化合物の放散量を測定する
大形テストチャンバー法に関する研究, 日本建 築学会環境系論文集，593，41-48(2005).

20）福井 清：半導体によるニオイセンサーの実際 と課題，公害と対策，26(4)，29-36(1990).

注1）：正式にはVOCsであるが，本報では一般に使 用されているVOCとした。

注2）：通常のオフィスビルでは, センサからの情報 (出力信号) は Building Energy Management System(BEMS)等のビル管理システムに渡され， 空調，照明や外気導入量を最適に制御されてい る。 